TP Periodica Polytechnica Mechanical Engineering

62(2), pp. 118-125, 2018

https://doi.org/10.3311/PPme.11034

Creative Commons Attribution (i)

RESEARCH ARTICLE

\section{Multi Response Optimization of Setting Input Variables for Getting Better Product Quality in Machining of Magnesium AM60 by Grey Relation Analysis and ANOVA}

\author{
S. P. Sundar Singh Sivam ${ }^{1 *}$, Sathiya Moorthy Karuppaiah ${ }^{2}$, Bhaskar
} Karthik Yedida $^{1}$, Jai Ram Atluri ${ }^{1}$, Shubhang Mathur ${ }^{1}$

Received 16 May 2017; accepted after revision 14 December 2017

\begin{abstract}
This study presents the optimization of Machining parameters on AM60 Mg alloy manufactured by Gravity Die Casting and with responses supported orthogonal array with Grey relation analysis. Focuses on the optimization of Machining input parameters using the technique to get minimum surface roughness, Minimum Tool Wear, Cutting Time, Power Requirement, Torque and Maximum MRR. A number of Machining trails were conducted based on the L9 orthogonal array on CNC machine. The experiments were performed on AM60 alloy using cutting tool of an ISO 460.1-1140-034A0-XM GC3 of 12,16 and $25 \mathrm{~mm}$ diameter with cutting point 140 degrees, throughout the experimental work under different cutting conditions. Grey relation analysis \& ANOVA were used to work out the fore most important parameters Cutting speed, feed rate, Depth of Cut and Tool Diameter which affects the Response. The expected response and measured response are fairly close. The given model could be used to select the level of Machining parameters.
\end{abstract}

\section{Keywords}

Mg Alloy, Different Cutting conditions, Grey Relation Analysis and $A N O V A$

\section{Introduction}

An incredible trouble in evolutionary computation is the correlation of calculations. For the most part, the calculations are run a few times to acquire different benchmarks. At that point, the outcomes are broke down by methods for measurable speculation tests [1-9]. The measurable tests can recognize if there are contrasts between the exhibitions of the calculations. The problem is if there are contrasts, which calculation is the best one? To utilize measurable tests in this progression, it is necessary to make pairwise examinations between the calculations. Clearly, the quantity of tests required increases incredibly with the quantity of calculations being broke down. This is risky, first on the grounds that the tire some work of looking at each match of calculations; also and more essential, the likelihood of committing an error increments. Finding an option with the most financially savvy or most astounding achievable execution under the given requirements, by boosting wanted factors and limiting undesired ones is known as process streamlining. Taguchi technique is an orderly and effectiveness way to deal with locates the ideal optimal of information parameters. This strategy uses the orthogonal exhibit of tests to decrease the quantity of analyses in any machining procedure. Utilizing the orthogonal exhibit nine trials has been directed. L9 orthogonal exhibit can't be utilized for this examination as 4 input parameters have been utilized, rather Grey connection investigation is utilized for the optimization. Magnesium combinations have been connected in different fields, for example, in car [1, 2], aviation [3], and convenient microelectronics [4, 5]. This is for the most part credited to the gentility of magnesium- $-33 \%$ lighter than aluminum, three-fourths than zinc, and four-fifths than steel [6]. Magnesium composites likewise have preferred machinability over other normally utilized metals [7]. The issue of chips making flashes amid get done with Machining has pulled in inquire about interests. Despite the fact that coolants can be utilized to avoid starts in Machining procedure of magnesium amalgams, dry machining is alluring as it encourages taking care of and recovery of chips. It can offer cost diminishment and an air without contamination [8]. Usually, in the shearing zone and in addition the device chip contact zone, the expansion 
in temperature on cutting apparatus and work piece significantly impacts instrument wear and the cutting procedure itself $[9,10]$. A change in natural mindfulness and expanding cost weights on modern ventures have prompted a basic thought of customary cooling ointments utilized as a part of most machining forms. Contingent upon the workpiece, the generation structure, and the creation area the costs identified with the utilization of cooling ointments run from $7-17 \%$ of the aggregate expenses of the fabricated work piece [12-15]. By forsaking customary cooling greases and utilizing the advances of dry machining or least amount oil (MQL), this cost part can be decreased essentially. Other than a change in the proficiency of the creation procedure, such an innovation change makes a commitment to the assurance of work [16-18] and the earth $[19,20]$. The decrease of considerable introduction to cooling ointments at the work put lessens the perils and enhances the work result in the meantime. Moreover, a venture can utilize eco-accommodating generation forms, which prompts a superior picture in the market [17-28]. Investigating and understanding the cutting procedure components is a key issue in building up a sparing and safe dry machining process. Past the reception of this new machining innovation, the development of machine apparatuses and their fringe hardware should likewise be considered [21]. Mechanical specialists may will to acknowledge dry machining innovation when far reaching arrangements exist. Subsequently, comes about for an extensive assortment of work piece materials and regular generation strategies are fundamental to demonstrate the prevalence of this creative machining innovation [15-24]. The execution of dry machining can't be proficient by just killing the cooling oil supply. Truth be told, the cooling ointment plays out a few essential capacities, which, in its nonattendance, must be assumed control by different segments in the machining procedure. Cooling oils diminish the rubbing, and along these lines the age of warmth, and disperse the produced warm. What's more, cooling oils are in charge of an assortment of optional capacities, similar to the vehicle of chips and in addition the cleaning of devices, work pieces and installations. They accommodate a failure free, robotized operation of the generation framework. Also, cooling oils help to give a uniform temperature field inside the workpiece and machine apparatus and help to meet determined resistances [21-30]. In the present Study, exploratory points of interest utilizing the Grey relation analysis of parameter configuration have been utilized for improving numerous execution attributes which incorporate least surface roughness (Ra), Min Tool Wear, Cutting Time, Power Requirement and Torque and Maximum MRR for Machining of Mg Alloy. To put it plainly, there is an abundant extent of applying the proposed technique of Grey relation analysis for the optimization of machining parameters of Mg Alloy and ANOVA for significant percentage contribution using the economical cutting tool of an ISO 460.11140-034A0-XM GC3 of different diameter with cutting point
140 degrees, which is utilized all through the trial work for the advantages of industries.

\section{Experimental Methods and Measurements}

The material utilized as a part of this investigation is AM60 magnesium cast combination and Experimental Setup, as appeared in Fig. 1, AM60 magnesium composite was processed by CNC HURCO machine (VM20). The rake angle for Sandvik Coromant carbide indexable face Machining is 450 and range of tidy up is $75 \mathrm{~mm}$. The width of cut is $25 \mathrm{~mm}$, which is equivalent to the width of workpiece. The BHN for both the materials is in the range of 45-60. For surface roughness measurement Taylor Hobson - Talysurf Surface roughness testing machines are used, Material Removal Rate (MRR) is measured by measuring the work-piece before and after the machining procedure with the assistance of computerized measuring machine, taking note of the machining time with the assistance of a stopwatch and finally dividing the weight removed during machining by machining time. Tool Wear (TW) was measured by image processing techniques in Tool Presetter manufactured by ZOLLER Germany. Cutting Time (CT) was measured by CNC Machine Timer in CPU, Power utilization was measured by utilizing two watt meter strategy. Two aligned wattmeter were utilized and their readings were included in the wake of increasing them with appropriate duplicating variable to get Power Consumption (PC) in Kilo watt. Torque sensor essentially comprises of a thin-walled chamber, and a piezo-resistive MEMS strain gage reinforced on the surface of the detecting component where the shear strains is Maximum. The strain gage incorporates eight piezo resistances and four are associated in a full Wheatstone circuit connect, which is utilized to quantify the connected torque constrain amid machining strategies.

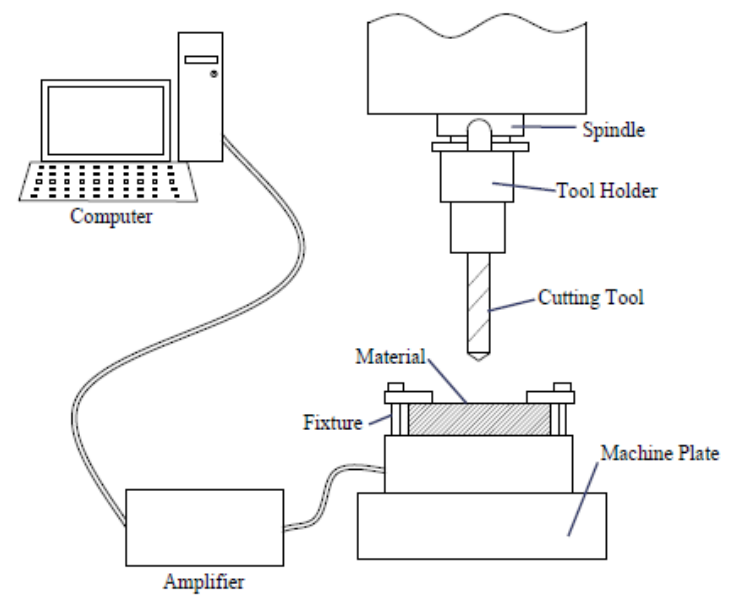

Fig. 1 Schematic Diagram for Experimental Setup

\subsection{Study of Chemical composition of element}

The chemical composition of AM60 material has been analyzed as per ASTM A751 - 11 standards by a spectro Machine Make Ametek, with a measuring range of $5 \mathrm{ppm}$, software used is Spectro spark analyzer pro MAXx for analytical operation 
and calibration is to ensure the chemical composition at different stages (Receiving of incoming alloy, melting metal and holding alloys). The observed composition of AM60 was tabulated in Table 1.

Table 1 Chemical composition of AM60.

\begin{tabular}{ccccccccc}
\hline Alloy & $\mathrm{Zn}$ & Mischmetal & $\mathrm{Si}$ & $\mathrm{Cu}$ & $\mathrm{Mn}$ & $\mathrm{Fe}$ & $\mathrm{Zr}$ & $\mathrm{Mg}$ \\
\hline AM60 & 4.16 & 4.15 & 0.12 & 0.03 & 0.12 & .003 & 0.85 & Balance \\
\hline
\end{tabular}

\subsubsection{Step 1: Grey relation generation}

The first step of Grey relation analysis is carried out by pre-processing of the output response data. It is performed for normalizing the data, which is shown in Table 2. In the case Maximum Thinning, higher the better performance characteristic is considered, and hence, it is normalized in the range between 0 to 1 using the formula (4) to avoid the effect of different units and to reduce the variability. The normalized output parameter for Maximum Thinning corresponding to the larger the better criterion is expressed as

$$
X_{i}^{*}(k)=\frac{X_{i}^{(0)}(k)-\min X_{i}^{(0)}(k)}{\max X_{i}^{(0)}(k)-\min X_{i}^{(0)}(k)}
$$

Similarly, the normalized output parameter for Maximum Thinning corresponding to the Higher the better criterion is expressed as.

$$
X_{i}^{*}(k)=\frac{\max X_{i}^{(0)}(k)-X_{i}^{(0)}(k)}{\max X_{i}^{(0)}(k)-\min X_{i}^{(0)}(k)}
$$

Where, $X_{i}^{*}(k)$ is the normalized value, is the maximum value of the sequence, is the desired sequence and is the minimum value of the sequence. $X_{i}^{(0)}(k)$ is the minimum value of the sequence.

\subsubsection{Step 2: Grey relational coefficients}

In the second step, the Grey relation coefficient is calculated to express the correlation between the best and actual experimental results for the both the responses. The Table 2, shows the Grey relation coefficient. It is expressed as.

$$
\begin{gathered}
\gamma x_{0}(k), x_{i}^{*}=\frac{\Delta_{\min }-C \Delta_{\max }}{\Delta_{o i}(k)+C \Delta_{\max }} \\
\Delta_{o i}(k)=\left\|X_{0}(k)-X_{i}^{*}(k)\right\| \\
\Delta_{\min }=\text { Smallest value of } \Delta_{o i}(k) \\
\Delta_{\max }=\text { largest value of } \Delta_{o i}(k)
\end{gathered}
$$

$\Delta_{o i}(k)$ : Different values for $X_{0}(k), X_{0}(k)$ denotes the sequences and $X_{i}^{*}(k)$ denotesthe comparability sequences. $\gamma$ is distinguishing or identified coefficient. If all the process parameters have equal weightage, then it is set to be 0.5 .

\subsubsection{Step 3: Grey relational Grade}

The third step of Grey relation grade is to determine the average Grey relational coefficient corresponding to each performance characteristics. The evaluation of the multi objective characteristic is based on the Grey relation grade, which is shown in Table 2. If the Grey relational grade has greater value, it indicates that concerned parameters combination is the optimum value. The Grey relational grade is expressed as follows,

$$
\tau_{i}=\frac{1}{n} \sum_{i=1}^{n}\left(\gamma\left(x_{o}(k), x_{i}^{*}(k)\right)\right.
$$

Where, $\tau_{i}$ the Grey relational grade, where $\mathrm{n}$ is the number of process responses. The higher Grey relation grade represents that the corresponding experimental results are considered to be closer to the ideal normalized value.

Table 2 Factors and Levels

\begin{tabular}{lcccc}
\hline Parameters & Unit & \multicolumn{3}{c}{ Levels } \\
& & 1 & 2 & 3 \\
\hline Cutting speed (V) & $\mathrm{m} / \mathrm{min}$ & 188 & 207 & 226 \\
Feed (F) & $\mathrm{mm} / \mathrm{rev}$ & .06 & .08 & 0.1 \\
Depth Of Cut (DOC) & $\mathrm{mm}$ & 0.5 & 1 & 1.5 \\
Tool Diameter (TD) & $\mathrm{mm}$ & 12 & 16 & 25 \\
\hline
\end{tabular}

\section{Experimentation Factors and Levels}

In the present Scenario, Machining of AM60 with minimum surface roughness, Tool Wear, Cutting Time, Power Requirement and Torque and Maximum MRR is a Challenge to manufacturing industries. In the present work Cutting speed (V), Feed (mm/rev), Depth of Cut (DOC) and Tool Diameter (mm) are taken as Process parameter and are individually controllable.

\section{Result and discussion}

The Chemical Composition and optimization parameter for getting the final response for the industrial benefits and mechanical product quality by Grey Relation Analysis Method were determined by the above said procedure. The observations were tabulated for discussion.

\subsection{Chemical Composition}

From Table 1, Zinc is utilized as a part of mix with magnesium to create change in room-temperature quality; be that as it may, it increments hot shortness when included sums more noteworthy than $1 \mathrm{wt} \%$ to magnesium compounds. Zinc is additionally utilized as a part of blend with zirconium, rare earths, or thorium to create precipitation hardenable magnesium amalgams having great quality. Zinc likewise defeats the unsafe destructive impact of iron and nickel pollutions that may be available in the magnesium combination. Uncommon earth metals are added to magnesium combinations either as Mischmetal or as didymium. Mischmetal is a characteristic 
Table 3 L9 Orthogonal array with factors and responses

\begin{tabular}{|c|c|c|c|c|c|c|c|c|c|c|}
\hline SI. No & $\begin{array}{c}\mathrm{V} \\
\mathrm{mm} / \mathrm{min}\end{array}$ & $\begin{array}{c}\mathrm{F} \\
\mathrm{mm} / \mathrm{rev}\end{array}$ & $\begin{array}{c}\text { DOC } \\
\mathrm{mm}\end{array}$ & $\begin{array}{l}\mathrm{TD} \\
\mathrm{mm}\end{array}$ & $\begin{array}{l}\mathrm{Ra} \\
\mu \mathrm{m}\end{array}$ & $\begin{array}{c}\text { TW } \\
\mu\end{array}$ & $\begin{array}{c}\text { MRR } \\
\mathrm{cm} 3 / \mathrm{min}\end{array}$ & $\begin{array}{l}\text { CT } \\
\text { Sec }\end{array}$ & $\begin{array}{l}\text { PR } \\
\mathrm{kw}\end{array}$ & $\begin{array}{c}\mathrm{T} \\
\mathrm{Nm}\end{array}$ \\
\hline 1 & 188 & 0.06 & 0.5 & 12 & 0.8525 & 0.0800 & 0.6074 & 121 & 1.0093 & 1.9336 \\
\hline 2 & 188 & 0.08 & 1 & 16 & 0.9270 & 0.0740 & 3.2363 & 113 & 4.0371 & 10.3128 \\
\hline 3 & 188 & 0.1 & 1.5 & 25 & 0.9700 & 0.0690 & 9.1020 & 106 & 7.2668 & 29.0046 \\
\hline 4 & 207 & 0.06 & 0.5 & 12 & 0.8725 & 0.0610 & 0.6688 & 94 & 1.2236 & 2.1291 \\
\hline 5 & 207 & 0.08 & 1 & 16 & 0.9470 & 0.0560 & 3.5633 & 87 & 4.8944 & 11.3550 \\
\hline 6 & 207 & 0.1 & 1.5 & 25 & 0.9900 & 0.0490 & 10.0219 & 77 & 8.8098 & 31.9359 \\
\hline 7 & 226 & 0.06 & 0.5 & 12 & 0.9525 & 0.0470 & 0.7302 & 79 & 1.4585 & 2.3245 \\
\hline 8 & 226 & 0.08 & 1 & 16 & 0.9700 & 0.0420 & 3.8904 & 71 & 5.8341 & 12.3972 \\
\hline 9 & 226 & 0.1 & 1.5 & 25 & 0.9900 & 0.0360 & 10.9418 & 62 & 10.5013 & 34.8672 \\
\hline
\end{tabular}

Table 4 Normalized values, Grey relation coefficient and Grey grades of responses

\begin{tabular}{|c|c|c|c|c|c|c|c|c|c|c|c|c|c|c|}
\hline \multirow{2}{*}{$\begin{array}{l}\text { Trail } \\
\text { No }\end{array}$} & \multicolumn{6}{|c|}{ Normalized $\mathrm{S} / \mathrm{N}$ ratio } & \multicolumn{6}{|c|}{ Grey relation co efficient } & \multicolumn{2}{|c|}{ Grey relation } \\
\hline & $\begin{array}{l}\mathrm{Ra} \\
\mu \mathrm{m}\end{array}$ & $\begin{array}{c}\text { TW } \\
\mu\end{array}$ & $\begin{array}{c}\text { MRR } \\
\mathrm{cm} 3 / \\
\min \end{array}$ & $\begin{array}{l}\mathrm{CT} \\
\mathrm{Sec}\end{array}$ & $\begin{array}{l}\text { PR } \\
\text { kw }\end{array}$ & $\begin{array}{c}\mathrm{T} \\
\mathrm{Nm}\end{array}$ & $\begin{array}{l}\mathrm{Ra} \\
\mu \mathrm{m}\end{array}$ & $\begin{array}{c}\text { TW } \\
\mu\end{array}$ & $\begin{array}{c}\text { MRR } \\
\mathrm{cm} 3 / \\
\min \end{array}$ & $\begin{array}{l}\mathrm{CT} \\
\mathrm{Sec}\end{array}$ & $\begin{array}{l}\text { PR } \\
k w\end{array}$ & $\begin{array}{c}\mathrm{T} \\
\mathrm{Nm}\end{array}$ & GRADE & RANK \\
\hline 1 & 0.0000 & 1.0000 & 0.0000 & 1.0000 & 0.0000 & 0.0000 & 0.3333 & 1.0000 & 0.3333 & 1.0000 & 0.3333 & 0.3333 & 0.5556 & 7.0000 \\
\hline 2 & 0.5604 & 0.9024 & 0.5787 & 0.8977 & 0.5918 & 0.5788 & 0.5322 & 0.8367 & 0.5427 & 0.8302 & 0.5506 & 0.5428 & 0.6392 & 4.0000 \\
\hline 3 & 0.8630 & 0.8147 & 0.9363 & 0.8020 & 0.8428 & 0.9363 & 0.7849 & 0.7296 & 0.8870 & 0.7163 & 0.7608 & 0.8871 & 0.7943 & 1.0000 \\
\hline 4 & 0.1547 & 0.6605 & 0.0333 & 0.6224 & 0.0822 & 0.0333 & 0.3717 & 0.5956 & 0.3409 & 0.5697 & 0.3527 & 0.3409 & 0.4286 & 9.0000 \\
\hline 5 & 0.7028 & 0.5533 & 0.6120 & 0.5065 & 0.6741 & 0.6121 & 0.6272 & 0.5282 & 0.5630 & 0.5033 & 0.6054 & 0.5631 & 0.5650 & 5.0000 \\
\hline 6 & 1.0000 & 0.3861 & 0.9696 & 0.3240 & 0.9250 & 0.9697 & 1.0000 & 0.4489 & 0.9427 & 0.4252 & 0.8696 & 0.9428 & 0.7715 & 3.0000 \\
\hline 7 & 0.7413 & 0.3339 & 0.0637 & 0.3624 & 0.1572 & 0.0637 & 0.6591 & 0.4288 & 0.3481 & 0.4395 & 0.3724 & 0.3481 & 0.4327 & 8.0000 \\
\hline 8 & 0.8630 & 0.1931 & 0.6423 & 0.2027 & 0.7490 & 0.6425 & 0.7849 & 0.3826 & 0.5830 & 0.3854 & 0.6658 & 0.5831 & 0.5641 & 6.0000 \\
\hline 9 & 1.0000 & 0.0000 & 1.0000 & 0.0000 & 1.0000 & 1.0000 & 1.0000 & 0.3333 & 1.0000 & 0.3333 & 1.0000 & 1.0000 & 0.7778 & 2.0000 \\
\hline
\end{tabular}

blend of uncommon earths containing around $50 \mathrm{wt} \%$ cerium, the rest of principally lanthanum and neodymium; didymium is a characteristic blend of roughly $85 \%$ neodymium and $15 \%$ praseodymium. Augmentations of uncommon earths increment the quality of magnesium combinations at raised temperatures. They additionally diminish weld breaking and porosity in throwing in light of the fact that they limit the solidifying scope of the amalgams. Zirconium has an intense grain refining impact on magnesium combinations. It is added to compounds containing zinc, uncommon earths, blend of these components, where it fills in as a grain refiner.

From Table 5, Feed per Tooth and Cutting Speed are found to be the most significant factors affecting the surface finish. Depth of cut and tool diameter contribute equally.

From Table 6, it can be inferred that cutting speed shows the maximum contribution in affecting the tool wear followed by feed per tooth. Depth of cut and tool diameter show Negligible contributions.

Table 7 indicates that Feed per Tooth has the greatest influence on Material Removal Rate. Cutting Speed, Depth of Cut and Cutting Tool Diameter have a very minimal influence.
Table 5 Results of ANOVA on Surface finish

\begin{tabular}{lcccccc}
\hline $\begin{array}{l}\text { Source of } \\
\text { variation }\end{array}$ & $\begin{array}{c}\text { Sum of } \\
\text { Squares }\end{array}$ & $\begin{array}{c}\text { Degree of } \\
\text { Freedom }\end{array}$ & $\begin{array}{c}\text { Mean } \\
\text { Square }\end{array}$ & F & F table & $\begin{array}{c}\% \\
\text { contribution }\end{array}$ \\
\hline CS & 0.0045 & 2 & 0.0023 & 11.33 & 4.2 & 23.39 \\
FPT & 0.0126 & 2 & 0.0063 & 31.45 & 4.2 & 64.94 \\
DOC & 0.0011 & 2 & 0.0006 & 2.83 & 4.2 & 5.84 \\
CTD & 0.0011 & 2 & 0.0006 & 2.83 & 4.2 & 5.84 \\
Error & 0.002 & 9 & 0.0002 & & & \\
Total & 0.0194 & 17 & & & & \\
\hline
\end{tabular}

Table 6 Results of ANOVA on Tool Wear

\begin{tabular}{lcccccc}
\hline $\begin{array}{l}\text { Source of } \\
\text { variation }\end{array}$ & $\begin{array}{c}\text { Sum of } \\
\text { Squares }\end{array}$ & $\begin{array}{c}\text { Degree of } \\
\text { Freedom }\end{array}$ & $\begin{array}{c}\text { Mean } \\
\text { Square }\end{array}$ & F & F table & $\begin{array}{c}\% \\
\text { contribution }\end{array}$ \\
\hline CS & 0.0016 & 2 & 0.0008 & 4.04 & 4.2 & 89.28 \\
FPT & 0.0002 & 2 & 0.0001 & 0.48 & 4.2 & 10.66 \\
DOC & 0.0000 & 2 & 0.0000 & 0.00 & 4.2 & 0.01 \\
CTD & 0.0000 & 2 & 0.0000 & 0.00 & 4.2 & 0.05 \\
Error & 0.0020 & 9 & 0.0002 & & & \\
Total & 0.0018 & 17 & & & & \\
\hline
\end{tabular}


Table 7 Results of ANOVA on Material Removal Rate

\begin{tabular}{|c|c|c|c|c|c|c|}
\hline $\begin{array}{l}\text { Source of } \\
\text { variation }\end{array}$ & $\begin{array}{l}\text { Sum of } \\
\text { Squares }\end{array}$ & $\begin{array}{l}\text { Degree of } \\
\text { Freedom }\end{array}$ & $\begin{array}{l}\text { Mean } \\
\text { Square }\end{array}$ & $\mathrm{F}$ & $\begin{array}{c}\mathrm{F} \\
\text { table }\end{array}$ & ১゚ \\
\hline $\mathrm{CS}$ & 1.1412 & 2 & 0.5706 & 2852.92 & 4.2 & 0.82 \\
\hline FPT & 137.5719 & 2 & 68.7860 & 343929.85 & 4.2 & 98.63 \\
\hline DOC & 0.3863 & 2 & 0.1932 & 965.86 & 4.2 & 0.28 \\
\hline CTD & 0.3863 & 2 & 0.1932 & 965.86 & 4.2 & 0.28 \\
\hline Error & 0.002 & 9 & 0.000200 & & & \\
\hline Total & 139.4858 & 17 & & & - & \\
\hline
\end{tabular}

Table 8, indicates that Cutting Speed has the greatest influence on Cutting Time followed by Feed per Tooth, Depth of Cut and Cutting Tool Diameter.

Table 8 Results of ANOVA on Cutting Time

\begin{tabular}{|c|c|c|c|c|c|c|}
\hline $\begin{array}{l}\text { Source of } \\
\text { variation }\end{array}$ & $\begin{array}{l}\text { Sum of } \\
\text { Squares }\end{array}$ & $\begin{array}{l}\text { Degree } \\
\text { of } \\
\text { Freedom }\end{array}$ & $\begin{array}{c}\text { Mean } \\
\text { Square }\end{array}$ & $\mathrm{F}$ & $\begin{array}{c}\mathrm{F} \\
\text { table }\end{array}$ & ১゚ \\
\hline $\mathrm{CS}$ & 2802.6667 & 2 & 1401.333 & 7006666.67 & 4.2 & 87.42 \\
\hline FPT & 400.6667 & 2 & 200.3333 & 1001666.67 & 4.2 & 12.50 \\
\hline DOC & 2.0000 & 2 & 1.0000 & 5000.00 & 4.2 & 0.06 \\
\hline CTD & 0.6667 & 2 & 0.3333 & 1666.67 & 4.2 & 0.02 \\
\hline Error & 0.002 & 9 & 0.000200 & & & \\
\hline Total & 3206.0000 & 17 & & & 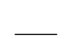 & \\
\hline
\end{tabular}

From Table 9, Feed per Tooth is found to be the most significant factor followed by Cutting Speed affecting the Power Requirement. Depth of Cut and Cutting Tool Diameter contribute equally.

Table 9 Results of ANOVA on Power Requiremen

\begin{tabular}{|c|c|c|c|c|c|c|}
\hline $\begin{array}{l}\text { Source of } \\
\text { variation }\end{array}$ & $\begin{array}{l}\text { Sum of } \\
\text { Squares }\end{array}$ & $\begin{array}{l}\text { Degree of } \\
\text { Freedom }\end{array}$ & $\begin{array}{c}\text { Mean } \\
\text { Square }\end{array}$ & $\mathrm{F}$ & $\begin{array}{c}\mathrm{F} \\
\text { table }\end{array}$ & ০゚ \\
\hline CS & 5.0099 & 2 & 2.5050 & 12524.82 & 4.2 & 5.31 \\
\hline FPT & 87.3297 & 2 & 43.6649 & 218324.30 & 4.2 & 92.63 \\
\hline DOC & 0.9707 & 2 & 0.4854 & 2426.87 & 4.2 & 1.03 \\
\hline CTD & 0.9707 & 2 & 0.4854 & 2426.87 & 4.2 & 1.03 \\
\hline Error & 0.002 & 9 & 0.000200 & & & \\
\hline Total & 94.2811 & 17 & & & $\bar{L}$ & \\
\hline
\end{tabular}

The purpose of the Table 5-10, is to investigate which of the process parameters significantly affect the performance characteristics. This analysis provides the relative contribution of machining parameters in controlling the response of machining performance criteria i.e. Grey relation analysis during Machining. The significance of a variable on the quality characteristic can be evaluated by using F-ratio. The F-ratio is the ratio of MS to the error. Generally, when $\mathrm{F}$ is greater than $\mathrm{P}$ - Value, it means that the change of experimental variables has a significant effect on the quality characteristics. The ANOVA table indicates that, Feed and Cutting speed are significant for all the responses ( $\mathrm{F}$ calculated value is more than the table value at $95 \%$ confidence level).

Table 10 Results of ANOVA on Torque

\begin{tabular}{|c|c|c|c|c|c|c|}
\hline $\begin{array}{l}\text { Source of } \\
\text { variation }\end{array}$ & $\begin{array}{l}\text { Sum of } \\
\text { Squares }\end{array}$ & $\begin{array}{l}\text { Degree } \\
\text { of } \\
\text { Freedom }\end{array}$ & $\begin{array}{l}\text { Mean } \\
\text { Square }\end{array}$ & $\mathrm{F}$ & $\begin{array}{c}\mathrm{F} \\
\text { table }\end{array}$ & ○ீ \\
\hline $\mathrm{CS}$ & 11.5870 & 2 & 5.7935 & 28967.39 & 4.2 & 0.82 \\
\hline FPT & 1397.1422 & 2 & 698.5711 & 3492855.57 & 4.2 & 98.63 \\
\hline DOC & 3.9236 & 2 & 1.9618 & 9809.03 & 4.2 & 0.28 \\
\hline CTD & 3.9236 & 2 & 1.9618 & 9809.03 & 4.2 & 0.28 \\
\hline Error & 0.002 & 9 & \multicolumn{2}{|l|}{0.000200} & & \\
\hline Total & 1416.5764 & 17 & & & - & \\
\hline \multicolumn{7}{|c|}{ Table 11 Results of ANOVA on GREY Grade } \\
\hline $\begin{array}{l}\text { Source of } \\
\text { variation }\end{array}$ & $\begin{array}{l}\text { Sum of } \\
\text { Squares }\end{array}$ & $\begin{array}{c}\text { Degree of } \\
\text { Freedom }\end{array}$ & $\begin{array}{l}\text { Mean } \\
\text { Square }\end{array}$ & $\mathrm{F}$ & F table & 을 \\
\hline $\mathrm{CS}$ & 0.0107 & 2 & 0.0053 & 26.73 & 4.2 & 6.67 \\
\hline FPT & 0.1459 & 2 & 0.0730 & 364.86 & 4.2 & 91.02 \\
\hline DOC & 0.0016 & 2 & 0.0008 & 4.11 & 4.2 & 1.02 \\
\hline CTD & 0.0021 & 2 & 0.0010 & 5.17 & 4.2 & 1.29 \\
\hline Error & 0.002 & 9 & 0.000200 & & & \\
\hline Total & 0.1603 & 17 & & & - & \\
\hline
\end{tabular}

From Fig. 2, it can be inferred that, Cutting Speed of 226 $\mathrm{mm} / \mathrm{min}$, feed rate of $0.1 \mathrm{~mm} / \mathrm{rev}$, depth of cut of $0.5 \mathrm{~mm}$ and cutting Diameter $12 \mathrm{~mm}$ are most optimum conditions for obtaining minimum torque.

From Fig. 3, it can be inferred that, Cutting Speed of 226 $\mathrm{mm} / \mathrm{min}$, feed rate of $0.1 \mathrm{~mm} / \mathrm{rev}$, depth of cut of $0.5 \mathrm{~mm}$ and cutting Diameter $12 \mathrm{~mm}$ are most optimum conditions for obtaining minimum Power Required.

Fig. 4, indicates that, Cutting Speed of $188 \mathrm{~mm} / \mathrm{min}$, feed rate of $0.06 \mathrm{~mm} / \mathrm{rev}$, depth of cut of $1.5 \mathrm{~mm}$ and cutting Diameter $25 \mathrm{~mm}$ are most optimum conditions for obtaining minimum tool wear.

Fig. 5, indicates that, Cutting Speed of $188 \mathrm{~mm} / \mathrm{min}$, feed rate of $0.06 \mathrm{~mm} / \mathrm{rev}$, depth of cut of $1.5 \mathrm{~mm}$ and cutting Diameter $25 \mathrm{~mm}$ are most optimum conditions for obtaining minimum cutting time. 
From Fig. 6, it can be inferred that, Cutting Speed of 226 $\mathrm{mm} / \mathrm{min}$, feed rate of $0.1 \mathrm{~mm} / \mathrm{rev}$, depth of cut of $0.5 \mathrm{~mm}$ and cutting Diameter $12 \mathrm{~mm}$ are most optimum conditions for obtaining maximum MRR.

From Fig. 7, it can be inferred that, Cutting Speed of 226 $\mathrm{mm} / \mathrm{min}$, feed rate of $0.1 \mathrm{~mm} / \mathrm{rev}$, depth of cut of $1.5 \mathrm{~mm}$ and cutting Diameter $16 \mathrm{~mm}$ are most optimum conditions for obtaining maximum surface finish.
Fig. 8, indicates that, Cutting Speed of $188 \mathrm{~mm} / \mathrm{min}$, feed rate of $0.1 \mathrm{~mm} / \mathrm{rev}$, depth of cut of $0.5 \mathrm{~mm}$ and cutting Diameter $12 \mathrm{~mm}$ are most optimum conditions according to the Grey Grade Values.

\section{Confirmation trails}

The affirmation analyse is led at the ideal settings to confirm the quality attributes for AM60Mg alloy by Machining process

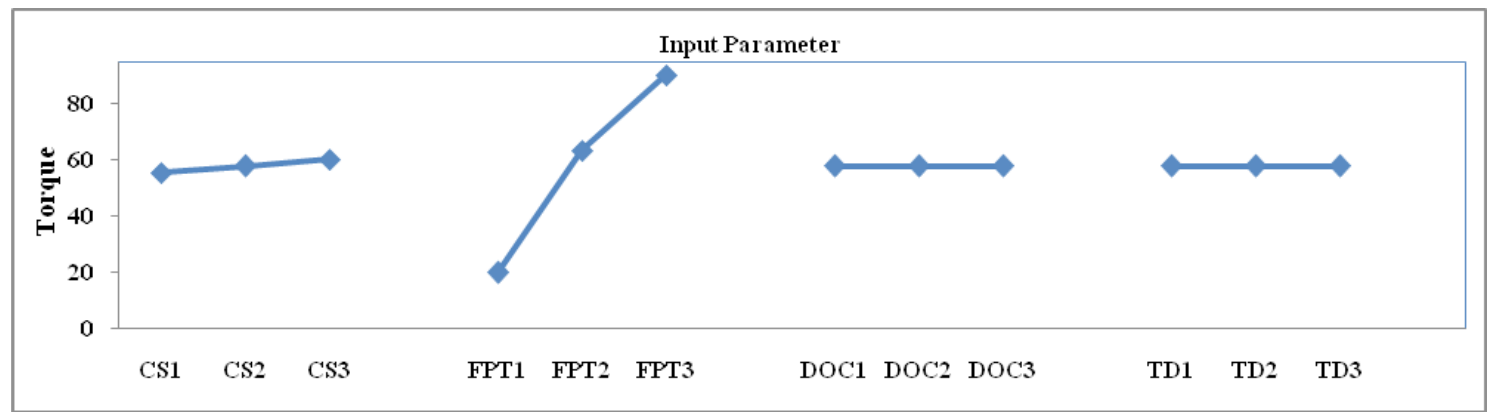

Fig. 2 Factor effects on Torque

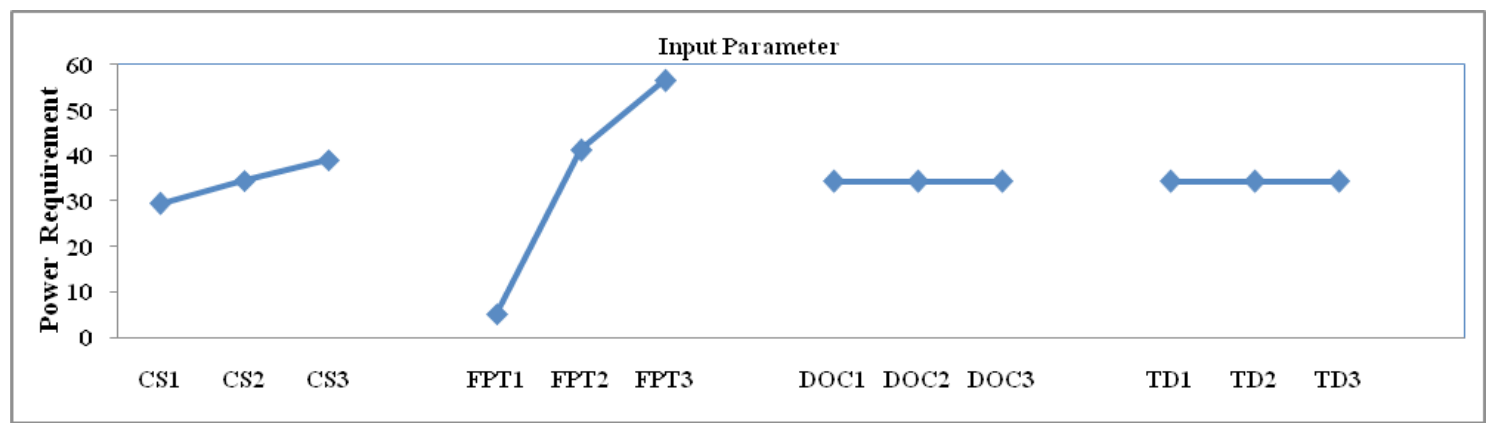

Fig. 3 Factor effects on Power Requirement

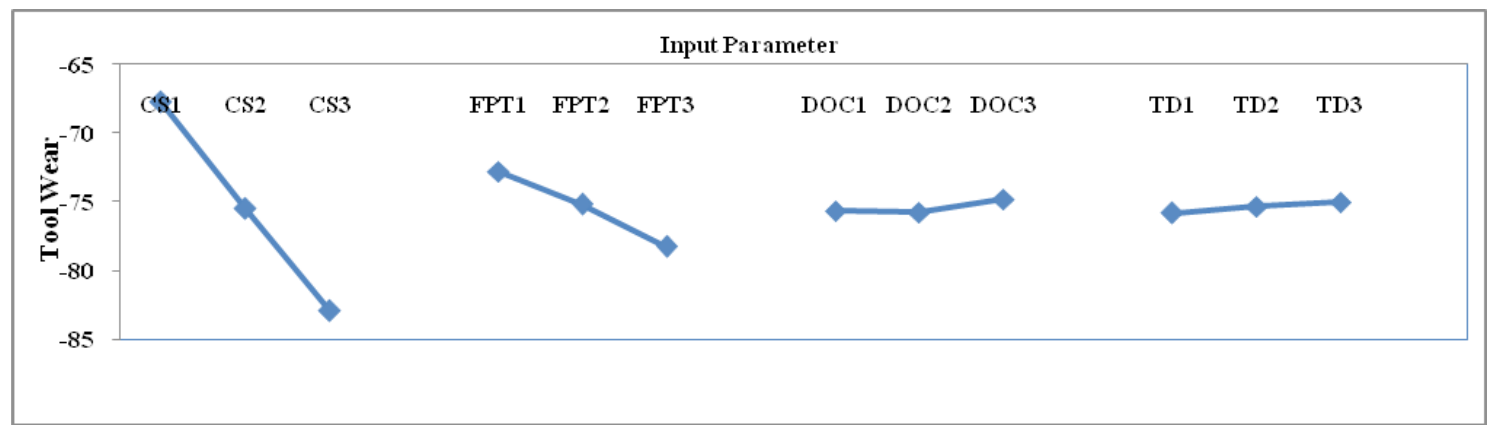

Fig. 4 Factor effects on Tool Wear

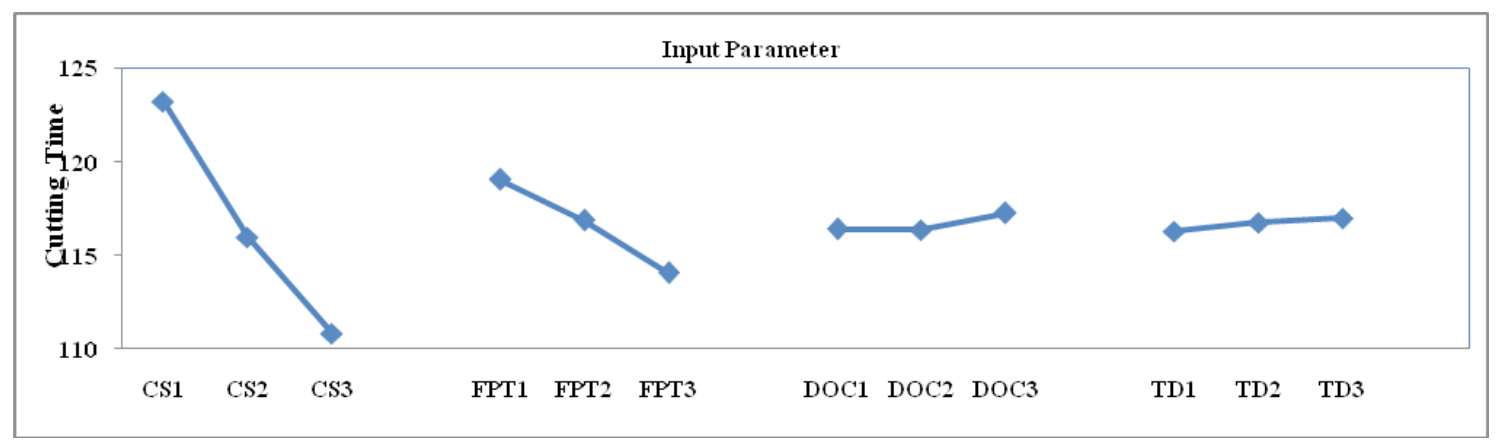

Fig. 5 Factor effects on Cutting Time 


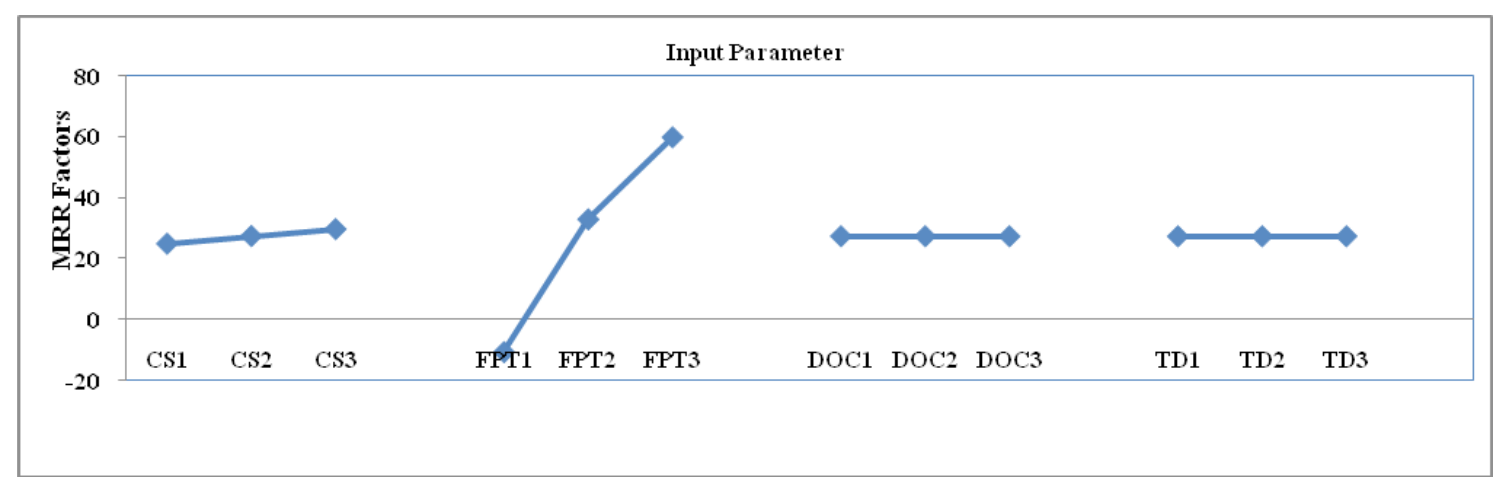

Fig. 6 Factor effects on MRR

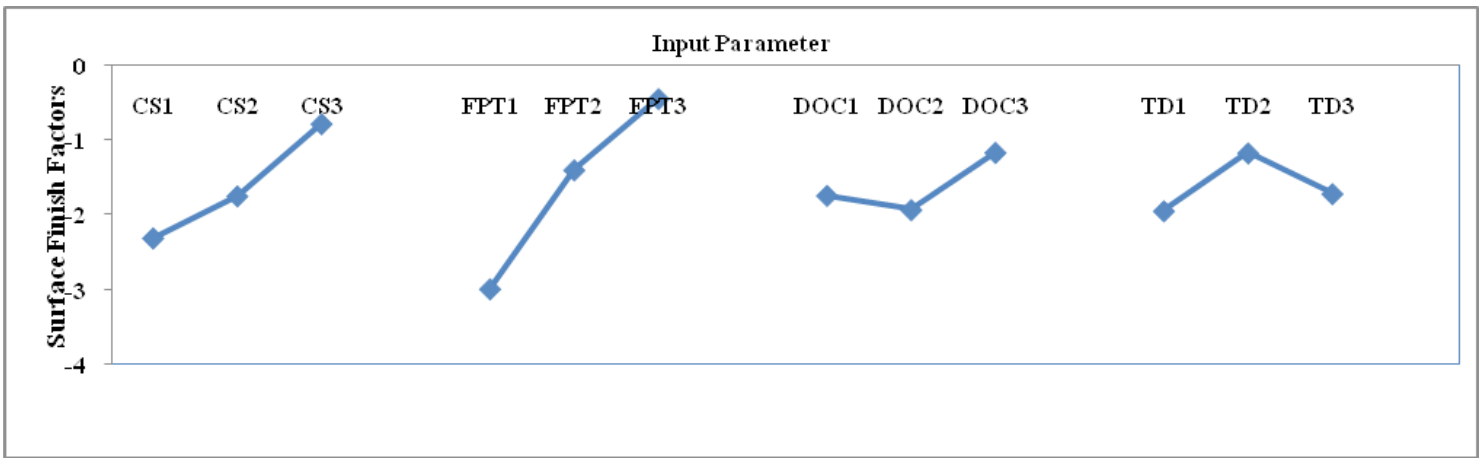

Fig. 7 Factor effects on Surface Finish

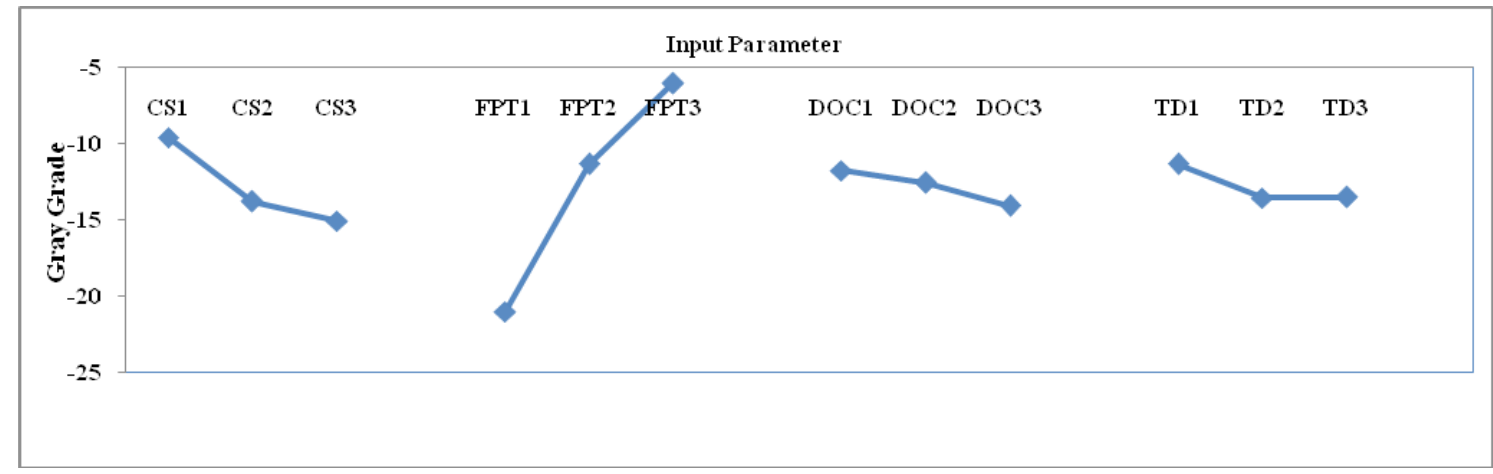

Fig. 8 Factor effects on grade values

prescribed by the examination. The reaction esteems by the affirmation try trial at the ideal settings are Cutting Speed of $207 \mathrm{~mm} / \mathrm{min}$, feed rate of $0.06 \mathrm{~mm} / \mathrm{rev}$, depth of cut of $0.5 \mathrm{~mm}$ and cutting Diameter $12 \mathrm{~mm}$. The Grey relation investigation review an incentive according to above dialog is observed to be 0.418 . Henceforth the Grey relation analysis for the advancement of the multi response issues is an extremely valuable tool for foreseeing the Output reactions.

\section{Conclusion}

The goal of this investigation was to discover the optimized combination of Cutting speed (V), Feed (F), Depth Of Cut (DOC) and Cutting Tool Diameters with the goal that the surface roughness (Ra), Tool Wear, Cutting Time, Power Requirement and Torque can be limited and MRR Maximized utilizing Grey relational examination and ANOVA, while Machining AM60
$\mathrm{Mg}$ alloy. Grey Relational analysis for the advancement of the multi reaction issues is an exceptionally valuable tool for positioning the base surface roughness ( $\mathrm{Ra}$ ), Tool Wear, Cutting Time, Power Requirement and Torque and Maximum MRR in the Machining of AM60. It does not include convoluted numerical hypothesis or calculation and consequently can be utilized by the architects without a solid statistical foundation. From this examination, it is uncovered that Cutting Speed and Feed are prominent factors which influence the Machining of AM60. The best execution qualities were gotten with AM60 when Machining the ideal parameters with the Cutting Speed of $207 \mathrm{~mm} / \mathrm{min}$, feed rate of $0.06 \mathrm{~mm} / \mathrm{rev}$ and depth of cut of $0.5 \mathrm{~mm}$ and cutting Diameter $12 \mathrm{~mm}$ for Environment Benefits. Confirmation test comes about demonstrated that the decided ideal mix of machining parameters fulfils the genuine prerequisites of Machining operation of AM60. 


\section{References}

[1] Davim, J. P. "Study of drilling metal-matrix composites based on the Taguchi Techniques." Journal of Materials Processing Technology. 132, pp. 250-254. 2003. https://doi.org/10.1016/S0924-0136(02)00935-4

[2] Mustafa, K. Ki. "Magnesium and its alloys applications in automotive industry." The International Journal of Advanced Manufacturing Technology. 39(9-10), pp. 851-865. 2008. https://doi.org/10.1007/s00170-007-1279-2

[3] Eliezer, A., Haddad, J., Unigovski, Y.; Gutman, E.M. "Static and dynamic corrosion fatigue of $\mathrm{Mg}$ alloys used in automotive industry." Materials and Manufacturing Processes. 20, pp. 75-88. 2005. https://doi.org/10.1081/AMP-200041636

[4] Campbell, F. C. "Manufacturing Technology for Aerospace Structure Material." Elsevier Press, United Kingdom. 2006.

[5] Ambat, R., Zhou, W. "Electroless nickel-plating on AZ91D magnesium alloy: Effect of substrate microstructure and plating parameters." Surface and Coatings Technology. 179(2-3), pp. 124-134. 2004. https://doi.org/10.1016/S0257-8972(03)00866-1

[6] Huang, Y. J., Hu, B. H., Pinwill, I., Zhou, W., Taplin, D. M. R. "Effects of process setting on the porosity levels of AM60B magnesium die castings." Materials and Manufacturing Processes. 15, pp. 97-105. 2000. https://doi.org/10.1080/10426910008912975

[7] Henry, H., Alfred, Y., Naiyi, L., John, E. A. "Potential magnesium alloys for high temperature die cast automotive applications: A review." Materials and Manufacturing Processes. 18, pp. 687-717. 2003. https://doi.org/10.1081/AMP-120024970

[8] Kainer, K. U., von Buch, F. "Modern development of alloys for light weight components." Material Wissenschaft und Werkstofftechnik. 30, pp. 159-167. 1999.

[9] Sreejith, P. S., Ngoi, B. K. A. "Dry machining: Machining of the future." Journal of Materials Processing Technology. 101, pp. 287-291. 2000. https://doi.org/10.1016/S0924-0136(00)00445-3

[10] Abukhshim, N. A., Mativenga, P. T., Sheikh, M. A. "Heat generation and temperature prediction in metal cutting: A review and implications for high speed machining." International Journal of Machine Tools and Manufacture. 46, pp. 782-800. 2006.

https://doi.org/10.1016/j.ijmachtools.2005.07.024

[11] Kitagawa, T., Kubo, A., Maekawa, K. "Temperature and wear of cutting tools in high-speed machining of Inconel 718 and Ti-6Al-6V-2Sn." Wear. 202(2), pp. 142-148. 1997. https://doi.org/10.1016/S0043-1648(96)07255-9

[12] Schirsch, R., Thamke, D., Zielasko, W. "Wirtschaftlichkeit der Trockenbearbeitung."(Economy of the Dry machining.) Trockenbearbeitung Prismatischer Teile, VDI Berichte. 1375, pp. 371-397. 1998. (in German)

[13] Weinert, K., Adams, F. J., Thamke, D. "Was kostet die." (How much is the.) Kühlschmierung?, Technica. 44(7), pp. 19-23. 1995. (in German)

[14] Thamke, D. "Technologische und ökonomische Aspekte der Trockenund Minimalmengenbearbeitung am Beispiel des Einlippentiefbohrens." (Technological and economic aspects of dry and dry Minimal quantity processing using the example of single lip deep drilling.) PhD Thesis, University of Dortmund, Germany, 1998. (in German)

[15] Kissler, H. "KSS-bedingte Kosten in der spanenden Metallbearbeitung als Anreiz für die Trockenbearbeitung." (KSS-related costs in metal cutting as an incentive for dry machining.) In: 12th International Colloquium Tribology 2000 - Plus, Conference Proceedings, 2: 901913. 2000. (in German)

[16] Chen, Z., Wong, K., Li, W., Stephenson, D. A., Liang, S. Y. "Cutting Fluid Aerosol Generation due to Spin-off in Turning Operation, Symposium on Manufacturing Science and Engineering." Conference Proceedings, ASME. 10, pp. 285-291. 1999.
[17] Gunter, K. L., Sutherland, J. W. "An Experimental Investigation into the Effect of Process Conditions on the Mass Concentration of Cutting Fluid Mist in Turning." Journal of Cleaner Production. 7(5), pp. 341-350. 1999. https://doi.org/10.1016/S0959-6526(99)00150-X

[18] Hands, D. M., Sheehan, J., Wong, B., Lick, H. B. "Comparison of Metalworking Fluid Mist Exposures from Machining with Different Levels of Machine Enclosure." American Industrial Hygiene Association Journal. 57(12), pp. 1173-1178. 1996. https://doi.org/10.1080/15428119691014305

[19] Howes, T. D., Tönshoff, H. K., Heuer, W. "Environmental Aspects of Grinding Fluids." CIRP Annals. 40(2), pp. 623-630. 1991. https://doi.org/10.1016/S0007-8506(07)61138-X

[20] Rossmoore, H. W. "Microbiology of Metalworking Fluids: Deterioration, Disease, and Disposal." Lubrication Engineering. 51(2), pp. 113-130. 1995.

[21] Aronson, R. B. "Why Dry Machining?." Manufacturing Engineering. 114(1), pp. 33-36. 1995.

[22] Klocke, F., Lung, D., Eisenblätter, G. "Mindermengenkühlschmierung - eine Alternative zur Nassberarbeitung?." (Low-volume cooling lubrication - an alternative to wet processing.) VDI-Berichte. 1240, 159190. 1996. (in German)

[23] Sundar Singh Sivam, S. P., Umasekar, V. G., Mishra, S., Mishra, A., Mondal, A. "Orbital cold forming technology - combining high quality forming with cost effectiveness - A review." Indian Journal of Science and Technology. 9(38), 2016. https://doi.org/10.17485/ijst/2016/v9i38/91426

[24] Sutherland, J. W., Kulur, V. N., King, N. C. "An Experimental Investigation of Air Quality in Wet and Dry Turning." CIRP Annals. 49(1), pp. 61-64. 2000. https://doi.org/10.1016/S0007-8506(07)62896-0

[25] Sundar Singh Sivam, S. P., UmaSekar, V. G., Saravanan, K., Rajendra Kumar, S., Karthikeyan, P., SathiyaMoorthy, K. "Frequently used Anisotropic Yield Criteria for Sheet Metal Applications: A Review." Indian Journal of Science and Technology. 9(47), 2016. https://doi.org/10.17485/ijst/2015/v8i1/92107

[26] Daniel, C. M., Olson, W. W., Sutherland, J. W. "Research Advances In Dry and Semi-dry Machining. SAE Technical Paper No. 970415 and SAE Transactions." Journal of Materials and Manufacturing. 106, pp. 373-383. 1997.

[27] Sundar Singh Sivam, S. P., Gopal, M., Venkatasamy, S., Singh, S. "An Experimental Investigation And Optimisation Of Ecological Machining Parameters On Aluminium 6063 In Its Annealed And Unannealed Form." Journal of Chemical and Pharmaceutical Sciences. pp. 46-53. 2015.

[28] König, W. "Fertigungsverfahren I - Drehen, Fräsen, Bohren." (Manufacturing Process I - Turning, Milling, Drilling.) Springer-Verlag, Berlin Heidelberg, 1999. (in German)

[29] Sundar Singh Sivam, S. P., Lakshmankumar, A., Sathiya Moorthy, K., Kumar, R. "Investigation exploration outcome of Heat Treatment on Corrosion Resistance of AA 5083 in Marine Application." International Journal of Chemical Sciences. pp. 15-22. 2015.

[30] Rajasekaran, A., Sundar Singh Sivam, S. P., Rajendrakumar, S., Saravanan, K. "Influence of setting variables in conventional super plastic forming process using Grey relation Analysis in Taguchi method." ARPN Journal of Engineering and Applied Sciences. 12(15), pp. 46484655. 2017. 